\title{
The Potential for Using Little Diomede Island as a Platform for Observing Environmental Conditions in Bering Strait
}

\author{
LEE W. COOPER, ${ }^{1,2}$ LOUIS A. CODISPOTI, ${ }^{3}$ VINCENT KELLY, ${ }^{3}$ GAY G. SHEFFIELD ${ }^{4}$ \\ and JACQUELINE M. GREBMEIER ${ }^{1}$
}

(Received 3 February 2005; accepted in revised form 25 August 2005)

\begin{abstract}
The Pacific waters that enter the Arctic via the Bering Strait exert a major influence on the Arctic Ocean's stratification, ice cover, and ecosystem. We demonstrate the potential of a shore-based laboratory to monitor the water masses that flow predominantly northward past Little Diomede Island in the center of the Bering Strait into the Arctic Ocean. We determined near-surface water column salinity, inorganic nutrient concentrations, natural fluorescence associated with chlorophyll, and the oxygen isotope composition of seawater, both in summer during the open-water period and in late winter under ice-covered conditions, by pumping ashore water from shallow depths near the island. Additional surveys were undertaken within $5 \mathrm{~km}$ of the island to assess the influence of local sources of nutrients. Water mass variability was much greater during the open-water period than under ice-covered conditions, presumably because the relatively immobile ice cover attenuates wind forcing and the decrease in run-off reduces cross-shelf gradients. The mean oxygen isotope composition of the summer $\left(\delta^{18} \mathrm{O}=-1.11 \%\right)$ and late winter $\left(\delta^{18} \mathrm{O}=-0.98\right)$ collections, however, was close to that which has been established for Bering Sea waters in the Pacific-dominated upper halocline of the Arctic Ocean (-1.1\%o) particularly considering the higher seasonal flow of runoff in the summer. A comparison with data from shipboard sampling at various locations across the Bering Strait indicates that the oxygen isotope composition of near-surface water sampled at Diomede varies in response to wind-forcing. If the least saline $(<30.5)$ water near the Alaska coast is excluded, the $\delta^{18} \mathrm{O}$ values of Diomede and shipboard samples cannot be distinguished statistically. This similarity suggests that the water sampled from the island also reasonably represents the $\delta^{18} \mathrm{O}$ value of Bering Sea waters that contribute to the upper halocline of the Arctic Ocean. Effects of benthic recycling, human activity, and seabird nesting on nutrient concentrations appeared to be concentrated within $\sim 200 \mathrm{~m}$ of the island. Our results are discussed in the practical context of availability of electricity, interested local residents, and a geotechnical study indicating that it is feasible to construct and operate a more permanent undersea water intake system to improve environmental observation capabilities in the Bering Strait region.
\end{abstract}

Key words: Diomede, Bering Strait, Arctic oceanography, oxygen isotopes, nutrients

RÉSUMÉ. Les eaux du Pacifique qui entrent dans l'Arctique par le détroit de Béring ont une influence majeure sur la stratification, le couvert de glace et l'écosystème de l'océan Arctique. Dans ce rapport nous présentons des données qui démontrent le potentiel d'un laboratoire basé à terre dans le but de surveiller les masses d'eau qui circulent principalement vers le nord au-delà de l'île Little Diomede au centre du détroit de Béring jusqu'à l'océan Arctique. Nous avons déterminé la salinité de la colonne d'eau près de la surface, la concentration des nutriments inorganiques, la fluorescence naturelle associée avec la chlorophylle, ainsi que la composition en isotope d'oxygène de l'eau de mer. Ces données ont été recueillies pendant la période estivale en eaux ouvertes et à la fin de l'hiver sous des conditions de couvert de glace en pompant à terre l'eau provenant d'aires peu profondes près de l'île. Des études supplémentaires ont été entreprises à moins de $5 \mathrm{~km}$ de l'île afin d'évaluer l'influence des sources locales de nutriments. La variabilité des masses d'eaux était plus grande pendant la période sans couvert de glace que pendant les conditions de couvert de glace. Ceci était vraisemblablement dû à l'atténuation de la force exercée par le vent sous le couvert de glace relativement immobile et à une réduction des gradients à travers le plateau provenant d'une réduction du ruissellement. La composition moyenne en isotope d'oxygène des collections de l'été $\left(\delta^{18} \mathrm{O}=-1.11 \% 0\right)$ et de fin d'hiver $\left(\delta^{18} \mathrm{O}=-0.98 \%\right.$ ) étaient cependant près de celle qui a été établie pour les eaux de la mer de Béring dans l'halocline supérieure de l'océan Arctique dominée par les eaux du Pacifique $\left(\delta^{18} \mathrm{O}=-1.1 \%\right)$, particulièrement compte tenu du flux saisonnier de ruissellement plus élevé pendant l'été. Une comparaison avec des données recueillies par bateau à plusieurs locations à travers le détroit de Béring indique que la composition en isotope d'oxygène près de la surface des eaux mesurée à Diomede varie en réponse à la force du vent. Lorsque l'eau moins saline $(<30.5)$ près de la côte de l'Alaska est exclue, les valeurs $\delta^{18} \mathrm{O}$ de Diomede et des échantillons recueillis par bateau ne peuvent être distingués statistiquement. Cette similarité suggère que l'eau échantillonnée à partir de l'île représente aussi raisonnablement les valeurs $\delta^{18} \mathrm{O}$ des eaux de la mer de Béring qui contribuent à l'halocline supérieure de l'océan Arctique. Les conséquences du recyclage benthique, des activités anthropogéniques et de la nidification des oiseaux de mer sur les concentrations de nutriments

\footnotetext{
${ }^{1}$ Department of Ecology and Evolutionary Biology, University of Tennessee, Knoxville, Tennessee 37996, U.S.A.

${ }^{2}$ Corresponding author: lcooper1@utk.edu

${ }^{3}$ University of Maryland Center for Environmental Science, Horn Point Laboratory, Cambridge, Maryland 21613, U.S.A.

${ }^{4}$ Alaska Department of Fish \& Game, 1300 College Road, Fairbanks, Alaska 99701, U.S.A.

(C) The Arctic Institute of North America
} 
semblent être concentrées à moins de $200 \mathrm{~m}$ de l'île. Nos résultats sont interprétés dans le contexte pratique de la disponibilité de l'électricité, de l'intérêt des résidents locaux et d'une étude géotechnique qui indique qu'un système permanent de prise d'eau sous-marin peut être construit et opéré afin d'améliorer les capacités d'observation environnementale dans la région du détroit de Béring.

Mots-clés : Diomede, détroit de Béring, océanographie de l’Arctique, isotopes d'oxygène, nutriments

Traduit par Catherine Lalande.

\section{INTRODUCTION}

The Bering Strait is the only connection between the Pacific and Arctic oceans, and by extension, the only Northern Hemisphere connection between the Pacific and Atlantic oceans. The predominantly northward flow through this shallow $(50 \mathrm{~m})$ strait and the relatively high nutrient content of its waters result in biological productivities in the Bering and Chukchi seas that are higher than in any other Arctic seas, and in spring and summer, rival those of any location in the world ocean (Sambrotto et al., 1984; Springer et al., 1996; Macdonald et al., 2004). The relatively low-salinity, Pacific-origin waters flowing north through Bering Strait also contribute to forming and maintaining the Arctic Ocean's cold halocline, which separates the warm $\left(>0^{\circ} \mathrm{C}\right)$ Atlantic layer in the deep Arctic Ocean from the freshened surface waters covered with sea-ice (Bauch et al., 1995; Ekwurzel et al., 2001; Steele et al., 2004). Although salinities in the Bering Strait inflow exceed those of ambient Arctic Ocean surface waters, they are low compared to those of the inflowing Atlantic waters. When normalized to a salinity of 34.8 , the volume of freshwater flowing through the Bering Strait is $1600-2500 \mathrm{~km}^{3}$ year $^{-1}$, equivalent to as much as 1.5 times the combined direct river runoff into the Arctic Ocean from the four largest Eurasian rivers, the Yenisey, the Lena, the Ob, and the Pechora (Aagaard and Carmack, 1989; Woodgate and Aagaard, 2005). Since freshwater inputs into the Arctic can influence the Atlantic Ocean's thermohaline circulation with potential globally significant influences on climate (Wijffels et al., 1992), and because the nutrients carried by the Bering Strait inflow heavily influence the regional Chukchi Sea ecosystem (Walsh et al., 1989; Grebmeier et al., 1995), this $80 \mathrm{~km}$ wide strait is a key point for monitoring Arctic Ocean processes affected by the Pacific inflow.

The importance of scientific observations within the Bering Strait has been recognized through support for moored oceanographic measurements (e.g., Roach et al., 1995; Woodgate and Aagaard, 2005). These automated measurements have increased our understanding of physical parameters (i.e., salinity, temperature, and current flow), but understanding of biological and chemical processes has languished by comparison, primarily because many biological and chemical variables are difficult to convert to electronic signals. Despite advances in fluorometers, oxygen sensors, and nutrient monitors, many biological and chemical measurements (e.g., plankton species composition, trace gas concentrations, stable and radioactive isotopes, and biological rates) require discrete observations or water samples that cannot yet be processed by automated mooring equipment. A sampling system that terminates in a shore-based laboratory, on the other hand, is essentially unhindered by sample size or power requirements and can be interfaced with complex analytical equipment. Another key advantage of an onshore sampling system is its capability to sample near-surface waters. Because of ice-keel effects in the Bering Strait, moored instruments are generally anchored well below the surface $(30-40 \mathrm{~m})$, so the timing of biologically important events (such as the spring phytoplankton bloom, nutrient depletion, organic carbon variation, and other surface-water changes) cannot easily be ascertained with conventional moorings. By improving our understanding of processes, time-series data from a shore-based observatory could have the added advantage of providing insight into shortterm observations made elsewhere in the Arctic. For example, a detailed oxygen isotope composition record for the water column could be used throughout the ice-growing season to provide a basis for understanding the annual variability in the oxygen isotope composition of bicarbonate in bivalves that record isotope ratios (e.g., Khim et al., 2003).

The limitations associated with moored platforms and the limited duration that is possible with shipboard observations have inspired an effort over the past several years to evaluate Little Diomede Island as an onshore platform for an ocean observation system that would augment moored and shipboard systems in the region (Fig. 1). The $5 \mathrm{~km}^{2}$ island is one of the two Diomede islands in the center of the Bering Strait, both of which are uplifted marine terraces composed of late Cretaceous hornblende granites (Gualtieri and Brigham-Grette, 2001). Little Diomede, Alaska, is currently home to an Iñupiat community $(\sim 150$ people) that depends heavily on harvesting local marine resources for subsistence. Sea ice normally freezes in the strait between Little and Big Diomede islands, creating a stable platform of landfast ice that links the two islands. Local traditional knowledge and our results indicate that it is possible to maintain a water intake system below the depth of ice keeling $(\sim 10 \mathrm{~m})$ between the two islands. Once this $2-3 \mathrm{~m}$ thick ice platform forms, often in January or February, it typically remains stable (it is used as a commercial runway until breakup in May), unlike the moving pack ice on the outer sides of the islands. Water depths between the two islands are up to $45 \mathrm{~m}$, similar to those in 


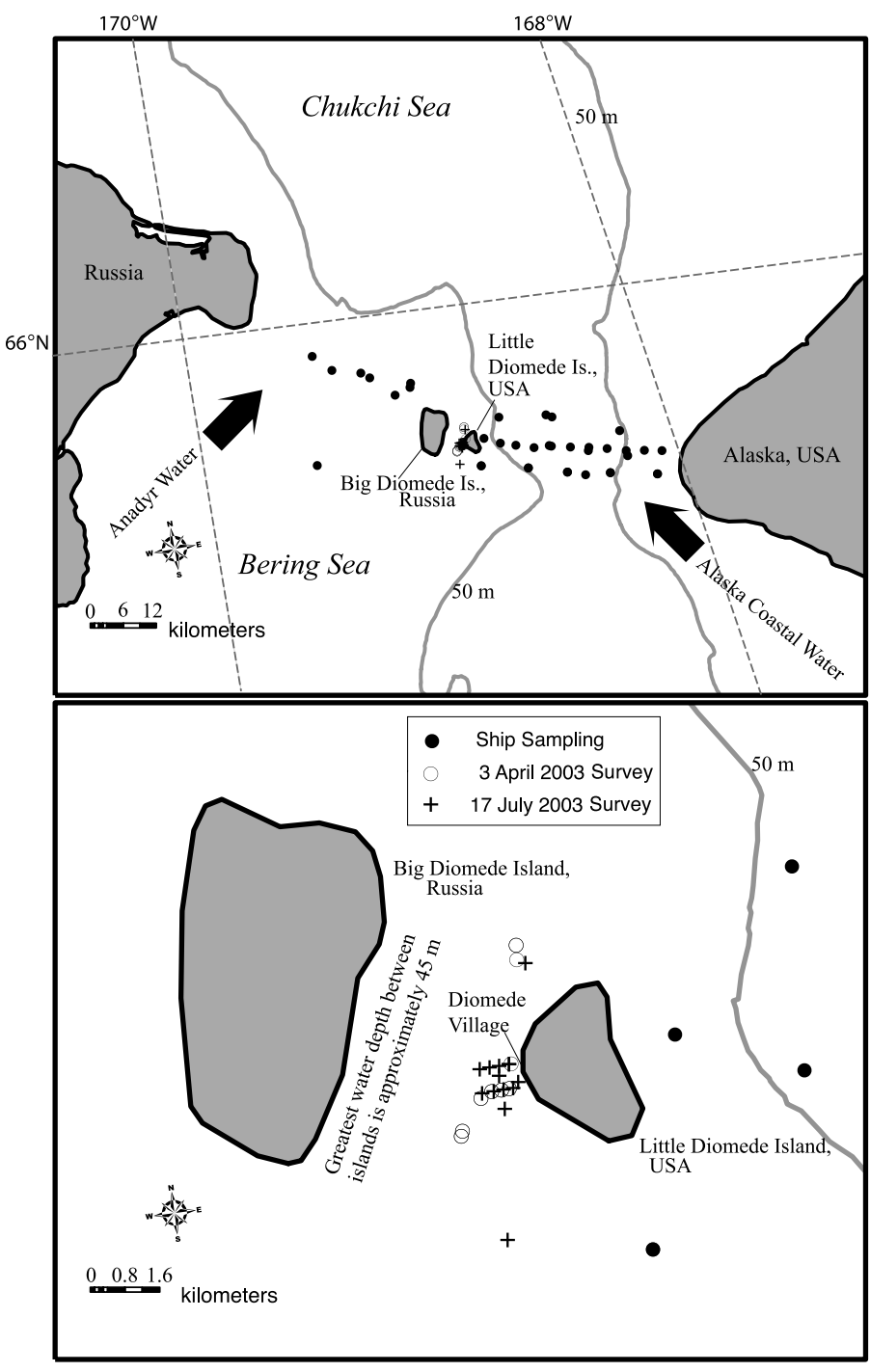

FIG. 1. Top panel shows location of Little and Big Diomede islands in the Bering Strait relative to the North American and Asian mainlands. Filled circles show locations where seawater samples were collected from the various shipboard platforms listed in Table 1. Open circles and crosses show locations of two nutrient surveys near the island. Bottom panel shows the near-island sampling points in more detail (as does Fig. 6). Grey line represents the $50 \mathrm{~m}$ isobath.

the remainder of the Strait, and current flow is predominantly northward. While sampling of near-surface waters could be problematic because of vertical structure in the water column, we were encouraged by the persistent high current flow (up to one meter per second) that can be observed from flotsam placed in the water from the island, which suggests strong vertical mixing. Available salinity profiles (from shipboard sampling locations shown on Fig. 1) show very little vertical structure in the portion of the Bering Strait adjacent to Diomede (Cooper et al., 2001), and the differences in the stable oxygen isotope composition of seawater collected at depths of $45 \mathrm{~m}$ relative to surface waters at Diomede are typically close to analytical uncertainty (L. Cooper, unpubl. data).

Other advantages for a laboratory at Diomede include the community's strategic location at the center of the
Bering Strait, the availability of line electricity from the Diomede Utilities Corporation to run instrumentation and pumping equipment, and recent improvements in communication infrastructure (satellite-based Internet access and a wireless local area network in the village). The Diomede community was originally located on this island for its position at a narrow point along marine mammal migration routes between the Bering and Chukchi seas, which include the strait between the two islands. The community depends on sea ice and ice-associated animals for food and materials. It follows that the support and knowledge of the local residents, as they attempt to anticipate and adapt to climatic changes that affect availability of these resources, will be important to the success of any environmental observation system based on the island.

Our project sought to determine the feasibility of pumping water ashore and directing it through analytical instrumentation, as well as providing a large-volume source for discrete water sampling. We focused initially on several parameters that reflect water-mass differences. Water masses vary significantly between nutrient-rich, saline Anadyr water originating on the west side of the Bering Strait and relatively nutrient-poor, freshened Alaska coastal water to the east (Coachman et al., 1975; Walsh et al., 1989; Fig. 1). Nutrients, particularly nitrate, are an important control on biological productivity, and recently developed automated instrumentation shows promise for extended, high-resolution nutrient measurements. To help assess biological processes that would affect nutrient concentrations, we also measured natural chlorophyll fluorescence using a flow-through fluorometer.

In addition, we also chose to measure the stable oxygen isotope composition of seawater in discrete samples. Although salinity, inorganic nutrients, and natural fluorescence are useful water-mass tracers, the stable oxygen isotope composition of seawater has additional utility in ice-covered seas. As sea-ice forms, underlying water salinity increases significantly through brine injection; however, oxygen isotope values remain little altered. These values are defined as $\delta^{18} \mathrm{O}=\left[\left({ }^{18} \mathrm{O} /{ }^{16} \mathrm{O}_{\text {sample }} \div{ }^{18} \mathrm{O} /{ }^{16} \mathrm{O}_{\mathrm{V} \text {-SMow }}\right)\right.$ - 1] $\times 1000(\mathrm{~V}-\mathrm{SMOW}$ is Vienna-Standard Mean Ocean Water). The transition from liquid water to solid ice results in a fractionation of the heavier isotope, so that the ice portion will be isotopically heavier by $2-3 \%$ o than the liquid water from which it forms. Over a water column $50 \mathrm{~m}$ deep (the depth of Bering Strait), however, the change in the $\delta^{18} \mathrm{O}$ values of underlying water from the formation of a $1 \mathrm{~m}$ sea-ice layer would be difficult to detect, given the analytical precision of the stable oxygen isotope measurement ( $\pm 0.05 \%$ to $0.10 \%$; Cooper, 1998). Because runoff water is significantly depleted in heavy isotopes as a result of evaporation, a reduction of salinity accompanied by a reduction in $\delta^{18} \mathrm{O}$ values is diagnostic of runoff contributions. By comparison, a reduction in salinity in the absence of significant changes in $\delta^{18} \mathrm{O}$ values is consistent with contributions of freshwater from melted sea ice. 
It is reasonable to expect that the oxygen isotope composition of water passing through the Bering Straitunlike nutrients, which are biologically consumed; salinity, which is changed by brine injection; and temperature, which decreases during northward transport-will not be significantly modified before it is incorporated into the Arctic Ocean's upper halocline and nutrient maximum. Independent evidence indicates that the upper Arctic Ocean halocline is derived from Pacific-origin waters flowing through the Bering Strait and that the mean $\delta^{18} \mathrm{O}$ value of the Pacific-derived contribution is $\sim-1.1 \%$ o (Macdonald et al., 1989; Bauch et al., 1995; Ekwurzel et al., 2001). If the mean $\delta^{18} \mathrm{O}$ value of water collected at Little Diomede Island in the center of the strait (Fig. 1) were close to this value, then it would be reasonable to conclude that water sampled from Little Diomede Island was similar in its oxygen isotope composition to the high-nutrient, Pacificderived water incorporated into the upper Arctic Ocean halocline. As another means to examine how representative samples collected at Diomede are of mean Bering Strait flow, we also compared the mean $\delta^{18} \mathrm{O}$ value of water collected at Diomede and its variation to the range of all available $\delta^{18} \mathrm{O}$ data available or reported for the Bering Strait.

A major consideration, however, is whether sampling from this island is significantly biased by local effects. Both Little and Big Diomede islands serve as large seabird colonies during the summer. Both islands also have human communities, so anthropogenic influences upon marine water quality cannot be ruled out. Since these islands form a physical barrier that influences water flow through the Strait, fluid dynamic boundary layers could also bias sampling. To assess such local effects, we directed a portion of our sampling efforts toward determining the spatial distribution of nutrients around the island in both open-water and ice-covered seasons. Our overall objective was to determine how far away from the island any permanent water intake system would need to be located. We did not investigate in detail the fluid dynamic boundary layers that may also bias sampling from the island relative to the Bering Strait as a whole, but we did compare nutrient concentrations measured south of the two islands to those of samples collected between the two islands (Fig. 1).

Photosynthetically active radiation was also measured in the water column to assess the depths at which biofouling by marine algae in the summer was likely to be reduced to a secondary challenge. For guidance on probable locations and depths for an intake system, we used a separate geotechnical study of the shoreline and seafloor made in March-April 2002 that assessed the feasibility of constructing a more permanent water intake system at Little Diomede Island (Peratovich, Nottingham and Drage, Inc., 2002).

Two other components of our Bering Strait Environmental Observatory research are being described elsewhere. Briefly, they are (1) annual shipboard sampling in areas of the Bering and Chukchi seas with high biological productivity to evaluate changes in benthic biological processes (e.g., Simpkins et al., 2003; Lovvorn et al., 2003, 2005; Clement et al., 2004; Cooper et al., 2005; Grebmeier et al., 2006) and (2) collection of marine mammal tissues obtained during subsistence hunting, which are being analyzed for a variety of biological and contaminant indicators (Dehn et al., 2005; See also http:// arctic.bio.utk.edu/Marine_mammals/index.html).

\section{METHODS}

Two types of pumping systems were used to collect water and bring it ashore along a $150 \mathrm{~m}$ pipeline $(120 \mathrm{~m}$ over water plus $30 \mathrm{~m}$ from shore to laboratory). In late winter, the heated and insulated pipeline was laid out on the ice, with the hose intake located at a depth of $6 \mathrm{~m}$, and supplied by a $10.2 \mathrm{~cm}$ diameter Goulds submersible well pump. In the open-water season (approximately June to November), the pipeline was submerged, and the onshore Goulds Model J+1.5 HP convertible jet pump used to transport water ashore was subject to more friction resistance, so the hose intake had to be located in shallower water. Thus practical considerations limited the range of these initial pumping systems to approximately $120 \mathrm{~m}$ from shore. Water from both pumping systems was routed via low temperature-tolerant, abrasion-resistant, flexible polyurethane tubing (Tygothane ${ }^{\circledR}$ from Norton Performance Plastics, Akron, Ohio) through a Seabird Electronics SBE 21 thermosalinograph. Following measurements of salinity and temperature (at one- minute intervals), smaller sub-flows of ambient seawater were directed through a Turner Designs 10-AU fluorometer configured for flowthrough measurements of natural fluorescence (at fiveminute intervals) and through WS Envirotech NAS-2E automated nutrient monitors for analyses (at $\sim$ two-hour intervals) of phosphate, nitrate, and in late-winter only, ammonium. Bottle samples for inorganic nutrients were also taken daily for analysis of additional nutrients and comparison with the automated systems. These bottle samples were returned frozen to the Horn Point Laboratory of the University of Maryland Center for Environmental Studies and analyzed for ammonium, nitrate + nitrite, phosphate, and silicate. Occasional nitrite determinations suggested that the concentrations of this species were generally low $(<0.25 \mu \mathrm{M})$. Slight modifications of JGOFS/ WOCE methods were employed for the analysis of nitrate + nitrite, nitrite, phosphate, and silicate (SCOR, 1996), and the method of Kérouel and Aminot (1997) was used for ammonium determinations. Analytical tolerance (1relative standard deviation) for nitrate + nitrite was $1.7 \%$ at $30.7 \mu \mathrm{M}$ with a detection limit ( 3 times the standard deviation of a zero concentration standard) of $0.5 \mu \mathrm{M}$; for ammonium (manual sampling), $3.1 \%$ at $3.0 \mu \mathrm{M}$ with a detection limit of $0.3 \mu \mathrm{L}$; for ammonium (automated sampling), $2.1 \%$ at $4.95 \mu \mathrm{M}$ with a detection limit of $0.3 \mu \mathrm{M}$; for phosphate, $0.7 \%$ at $3.16 \mu \mathrm{M}$ with a detection limit of 
TABLE 1. Sources of $\delta^{18} \mathrm{O}$ and salinity data from shipboard sampling in the Bering Strait.

\begin{tabular}{|c|c|c|c|}
\hline Ship & Date & Number of Samples & Data Sources ${ }^{1}$ \\
\hline Akademik Koralev & September 1988 & 1 & Grebmeier et al., 1990 \\
\hline Surveyor & September 1990 & 6 & Cooper et al., 1997 \\
\hline Alpha Helix $166^{2}$ & September 1992 & 15 & Cooper et al., 1997 \\
\hline Alpha Helix 171 & July 1993 & 8 & Cooper et al., 1997 \\
\hline Okean & August 1993 & 4 & Cooper et al., 1999 \\
\hline Sir Wilfrid Laurier & July 2000 & 15 & This study \\
\hline Sir Wilfrid Laurier & July 2001 & 33 & This study \\
\hline Alpha Helix 250 & September 2001 & 30 & This study \\
\hline Sir Wilfrid Laurier & July 2002 & 8 & This study \\
\hline Alpha Helix 260 & June 2002 & 28 & This study \\
\hline USCGC Healy 02-03 & July 2002 & 10 & This study \\
\hline Alpha Helix 274 & July 2003 & 92 & This study \\
\hline
\end{tabular}

${ }^{1}$ Raw data for many of these cruises are available at http://arcss.colorado.edu/.

${ }^{2}$ The numbers after a ship name refer to specific cruises by that ship.

$0.07 \mu \mathrm{M}$; and for silicate, $2.0 \%$ at $36.2 \mu \mathrm{M}$ with a detection limit of $0.2 \mu \mathrm{M}$.

Small seawater samples were also collected for measurements of stable oxygen isotope composition. These measurements were undertaken at the University of Tennessee, using an automated carbon dioxide equilibration system linked to a Finnigan Delta Plus stable isotope mass spectrometer. Repeated analyses of an internal water sample run concurrently with the samples indicate that the analytical precision was $\pm 0.04 \%$ (standard deviation; number of internal standards analyzed $[n]=14$ ).

We compared salinity and $\delta^{18} \mathrm{O}$ values for waters collected at Diomede with values obtained through shipboard sampling efforts in the Bering Strait, including almost all stable isotope data and associated salinities that to our knowledge are available (Table 1; locations shown on Fig. 1).

Nutrient surveys were undertaken in both ice-covered and open-water seasons to assess whether samples collected from the water intake were biased by proximity to the Diomede islands. During spring sampling, we drilled holes through the ice and used a battery-operated marine bilge pump to draw water samples from surface and bottom waters. Summer sampling was conducted from a small boat. These nutrient surveys sampled up to 12 stations sequentially. Whenever possible, each station was sampled twice during each survey. The re-sampling was done as soon as practical after the initial sampling (at two-tothree hour intervals over a $\sim$ six-hour sampling period) to help resolve any spatial or temporal variation. Both surface and near-bottom water samples were collected, in waters that ranged from $2 \mathrm{~m}$ to $20 \mathrm{~m}$ in depth. A Garmin Etrek Vista global positioning system was employed for navigation (the geographical coordinates for sampling are discussed and displayed in the results section).

In order to assess the annual maximum underwater light field at depths practical for a permanent water-intake system, we measured the penetration of photosynthetic active radiation directly west of Diomede Village on 17 July 2003, in water depths of $15 \mathrm{~m}$, using a submersible
Biospherical Instruments 510 radiometer. Measurements were made from a small boat and recorded on a portable computer.

To assess surface wind impacts on water properties, we used wind speed data collected hourly during our sampling period at the Nome Airport. This U.S. National Weather Service station is the nearest location to Diomede with archived surface wind data. These data were obtained from the U.S. National Climatic Data Center in Asheville, North Carolina.

\section{RESULTS}

We present selected data from two representative periods of continuous water sampling, an open-water period (30 July to 1 September 2001; Fig. 2) and an ice-covered period (30 March to 8 May 2003; Fig. 3). Water-mass variability was much greater during the open-water season than under ice-covered conditions. We hypothesized several possible causes: 1) ice cover reduces the impact of surface winds on water-mass distributions in Bering Strait; 2) temperatures and salinities are more uniform during winter and spring, when all water masses are near the freezing point and runoff is reduced; and 3) currents and distributions of water masses change from season to season. In summer, surface waters flowing northward past Little Diomede Island during or shortly after southerly wind events (Fig. 2a) had relatively high nutrient concentrations (nitrate $>10 \mu \mathrm{M}$; Fig. 2d), low temperatures $\left(<4^{\circ} \mathrm{C}\right.$; Fig. $\left.2 \mathrm{c}\right)$, and high salinity ( $>32$; Fig. 2b). After northerly surface winds (Fig. 2a), nitrate and phosphate concentrations decreased, salinities fell below 32, and temperatures rose above $4^{\circ} \mathrm{C}$.

Comparison of our data with wind measurements from the Nome airport suggests that water mass characteristics at Little Diomede are correlated with winds at Nome, with a time lag of approximately 72 hours. This $\sim 72$-hour lag between shifts in wind direction and changes in the water mass was identified empirically by testing the statistical 


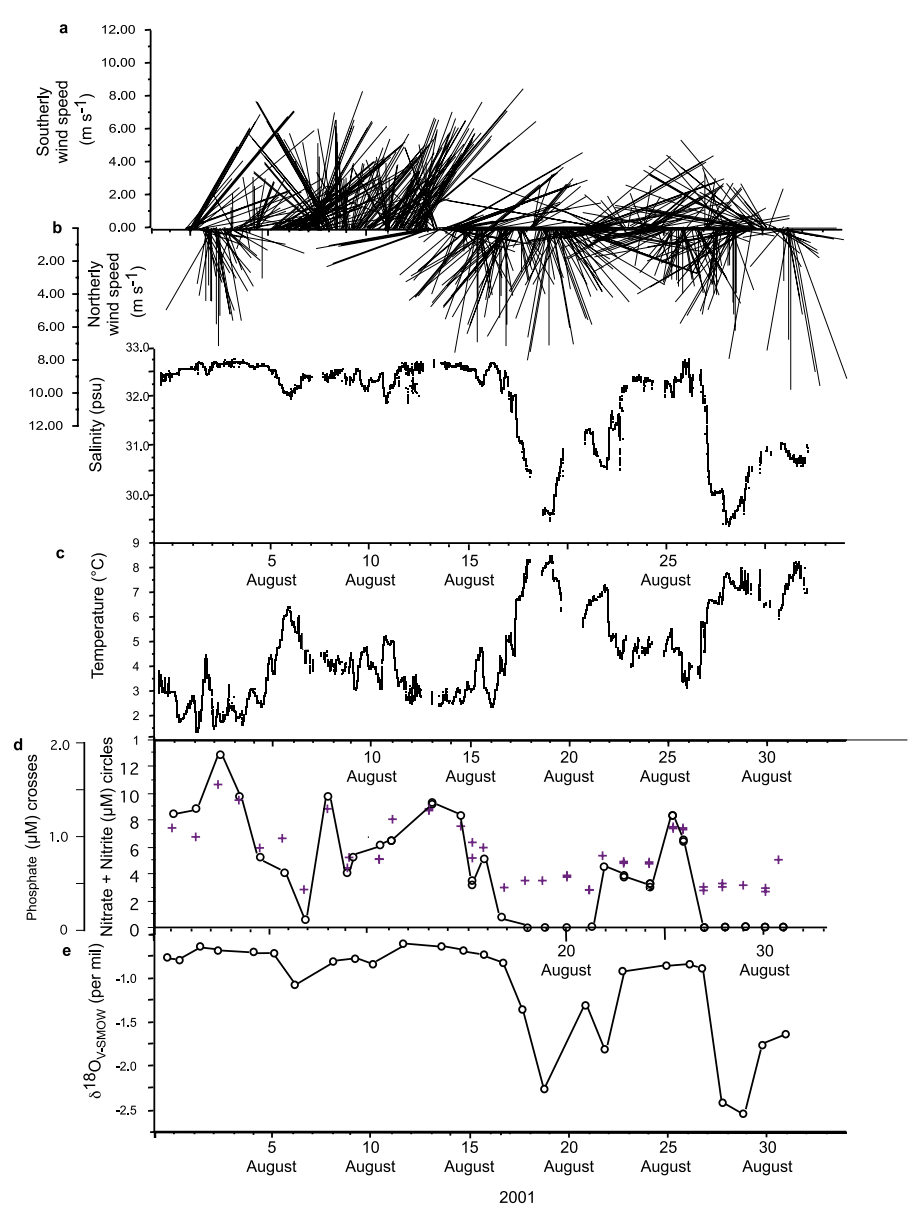

FIG. 2. Selected water-column data, (a) wind direction, (b) salinity, (c) temperature, (d) nutrients, and (e) $\delta^{18} \mathrm{O}$, collected from 30 July to 1 September 2001 at Little Diomede Island. Surface wind speed and direction (a) are from U.S. National Weather Service observations at Nome, Alaska. Changes in wind direction correspond with variation occurring in the water mass after a time lag of about 72 hours. Northerly winds increase the influence of Alaska coastal water (low nutrients, low salinity, and warmer temperatures), while southerly winds increase the influence of Anadyr water (high nutrients, high salinity, and colder temperatures).

significance of comparisons between salinity and wind vector (and temperature and wind vector) at various time intervals (e.g., no delay, 24 hours, 48 hours) after the wind vector observations. We classified these wind data into three simple categories: northerly (with compass bearing origins less than $90^{\circ}$ and greater than $270^{\circ}$ ), southerly (with compass bearing origins greater than $90^{\circ}$ and less than $270^{\circ}$ ), and calm conditions (when wind speeds were not significant). Analysis of variance found that mean water temperature and salinity measurements 72 hours after southerly wind observations were significantly different from those taken 72 hours after northerly wind observations.

Some limitations are associated with our analysis of water-mass characteristics in relation to wind observations made 72 hours earlier. For example, this simple analysis does not place any additional weight on high wind events and on wind duration. In addition, the length of our record does not permit rigorous determination of effective degrees of freedom (e.g., Leith et al., 1973; Harrison and

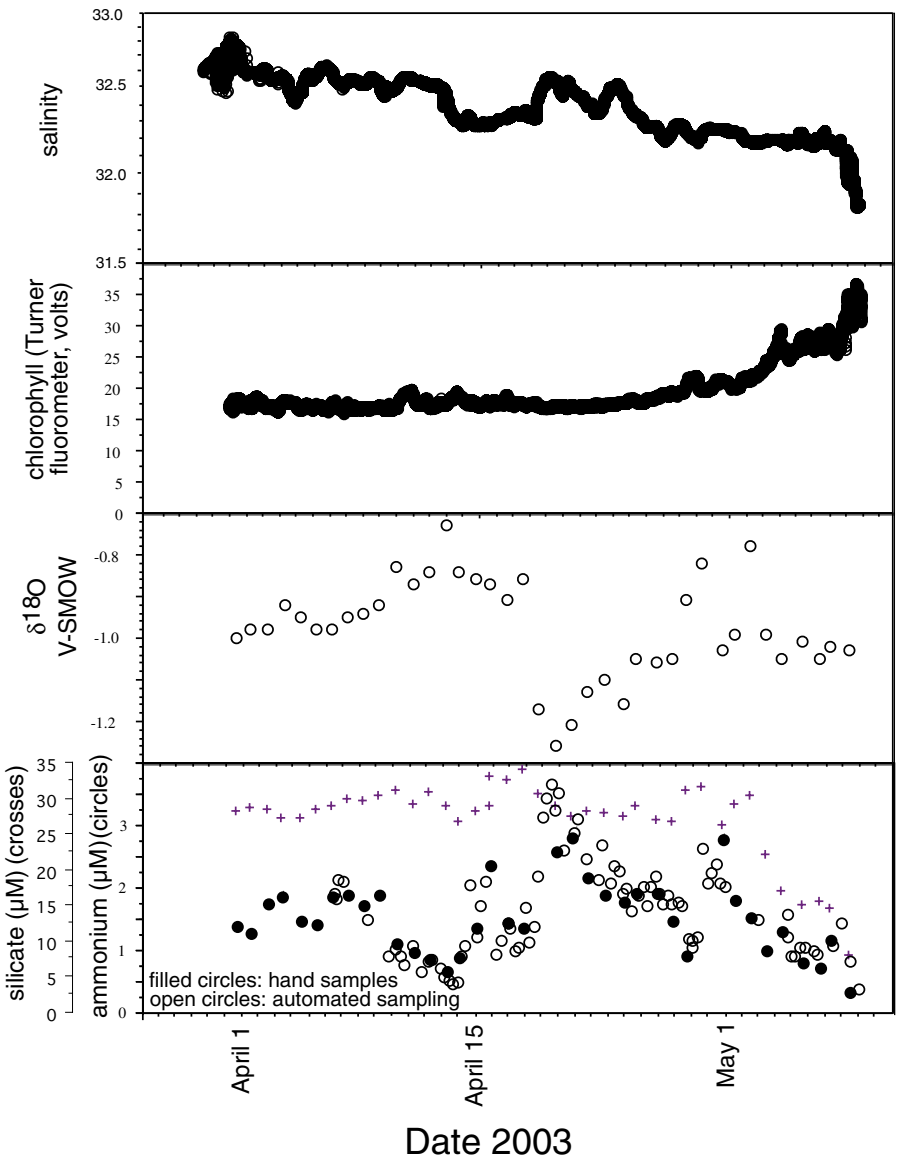

FIG. 3. Selected water-column data collected from 30 March to 8 May 2003 through a submerged pumping system located $120 \mathrm{~m}$ offshore from the Diomede Village High School. The decline in salinity is likely due to melting of sea ice farther south in the Bering Sea, as the $\delta^{18} \mathrm{O}$ value would show greater change if runoff had contributed. The increase in chlorophyll and the decreases in ammonium and silicate signal the onset of the spring phytoplankton bloom. Not shown are three anomalous (off-scale) values obtained from the NAS nutrient monitor and the data on phosphate and nitrate + nitrite, which also declined to low levels by early May.

Larkin, 1997) to filter out other cyclic and auto-correlated variations, such as diurnal influences on wind speeds and seasonal changes in radiation. Despite these limitations, we think that our interpretation of the association of watercolumn data and lagged wind vectors may be instructive for future research efforts in the Bering Strait. Our analysis used a reduced number of data, specifically once-hourly temperature and salinity data, to test for differences in the mean salinity and temperature of water 72 hours after wind observations. Unpaired t-tests showed that 72 hours after northerly wind observations, salinity was significantly lower (unpaired t-test; $p<0.0001$ ) and mean temperature was significantly higher (unpaired t-test; $p<0.003$ ) than they were 72 hours after southerly wind vectors were observed (Tables 2 and 3). Similarly, 72 hours after an observation of southerly winds, salinity was significantly higher and mean water temperatures were significantly lower than they were 72 hours after an observation of northerly winds. Figures 4 and 5 show these changes 
TABLE2. Mean salinities and temperatures 72 hours after wind observations at the Nome Airport. Water-column data from Little Diomede Island, 30 July to 1 September 2001.

\begin{tabular}{|c|c|c|c|}
\hline $\begin{array}{l}\text { Wind Vector Comparison } \\
72 \text { Hours after Observation }\end{array}$ & Mean Salinity & Standard Deviation & Number of Measurements \\
\hline All Data & 31.81 & 1.04 & 24583 \\
\hline Northerly & 31.33 & 1.07 & 8151 \\
\hline Southerly & 31.95 & 1.01 & 11956 \\
\hline \multirow[t]{2}{*}{ Calm } & 31.59 & 0.82 & 1548 \\
\hline & Mean Temperatur & & \\
\hline All data & 4.78 & 1.92 & 24583 \\
\hline Northerly & 6.09 & 1.41 & 8151 \\
\hline Southerly & 4.43 & 1.72 & 11956 \\
\hline Calm & 5.47 & 1.38 & 1548 \\
\hline
\end{tabular}

TABLE 3. Unpaired t-test for difference in salinity and temperature at Diomede 72 hours after wind vector observations at the Nome Airport. Water data collection was from 30 July to 1 September 2001. Salinity and temperature data used were those collected exactly 72 hours after each hourly wind observation. Intervening salinity and temperature data collected each minute (mean values shown in Table 2) were not used in order to approximate the number of independent measurements (effective degrees of freedom) for an unpaired t-test. See text for additional details.

\begin{tabular}{|c|c|c|c|}
\hline $\begin{array}{l}\text { Wind Vector Comparison } \\
72 \text { Hours after Observation }\end{array}$ & Degrees of freedom used & t-value & $p$-value \\
\hline \multicolumn{4}{|l|}{ Salinity } \\
\hline Northerly-southerly & 480 & -4.651 & $p<0.0001$ \\
\hline \multicolumn{4}{|l|}{ Temperature } \\
\hline Northerly-southerly & 480 & 2.956 & $p=0.003$ \\
\hline
\end{tabular}

graphically. The coldest water temperatures $\left(<3.5^{\circ} \mathrm{C}\right)$ and highest salinities $(>32.6)$ were observed only $\sim 72$ hours after southerly wind observations. The fact that southerly winds did not always result in these low temperatures and high salinities presumably reflects the persistence and intensity of the winds and differences in the overall wind fields between Nome and Diomede. When these changes are observed, the apparent $\sim 72$ hour delay between shifts in wind direction and changes in the water mass may reflect the time required to establish a new water-mass boundary between Anadyr and Alaska coastal waters within the Strait.

The mean $\delta^{18} \mathrm{O}$ value of seawater we measured in $\mathrm{Au}$ gust 2001 (Fig. 2e) was $-1.11 \%$ $\pm 0.56 \mathrm{SD}(\mathrm{n}=33)$, the same as the mean value $(-1.1 \%$ o $)$ that has been established for the oxygen isotope composition of water in the upper halocline of the Arctic Ocean (Macdonald et al., 1989; Cooper et al., 1997; Ekwurzel et al., 2001).

As noted above, sampling during late winter (Fig. 3) showed much lower variability in salinity and stable oxygen isotope ratios. Salinity decreased over the recorded period as seasonal ice melt increasingly diluted surface waters, and a sharp increase in chlorophyll was recorded as the sea ice melted in the immediate vicinity (Fig. 3). Changes in the oxygen isotope composition of the seawater over this sampling period are modest compared to those observed in the summer sampling (Fig. 2), indicating that sea ice melt, rather than any significant water mass change, is the predominant source of the salinity decrease. The difference between the two sampling periods is particularly obvious when the summer and late winter samples are plotted together against salinity (Fig. 6).

From the equation, $\delta^{18} \mathrm{O}=\mathrm{x}$ (salinity) $+\mathrm{y}$, the $\mathrm{y}$ intercept can provide an estimate of the oxygen isotope composition of the freshwater end-member in a system such as this, in which freshwater-consisting of runoff, including direct precipitation minus evaporation, or melted sea ice, or both-mixes with seawater. For the summer sampling, $\delta^{18} \mathrm{O}=0.59 *$ salinity $-20.0 \%$; $\mathrm{r}^{2}=0.97$, meaning that by the time of this sampling in August 2001, the overall oxygen isotope composition of the freshwater component $\left(\delta^{18} \mathrm{O}=\sim-20 \pm 0.6 \%\right.$ o SE) was very close to that of runoff in the Bering Sea (Cooper et al., 1997). In other words, there was no remaining significant signal that could be attributed to melted sea ice. The late winter sampling, in contrast, shows no significant relationship between salinity and $\delta^{18} \mathrm{O}$ values $(p>0.05)$, and the shift downwards in salinity (from 32.8 to 31.9 ) during sampling is not synchronous with low-level variability $( \pm 0.4 \%$ ) in the oxygen isotope composition of the sampled water. Similar-scale changes in salinity during the summer sampling (e.g., from 32.0 on 17 August to 30.0 on 19 August 2001; Fig. 2) were synchronous with a decrease in $\delta^{18} \mathrm{O}$ values of $\sim 2 \%$ (Fig. 2). This indicates the runoff component in the water sampled in late winter must be small. 


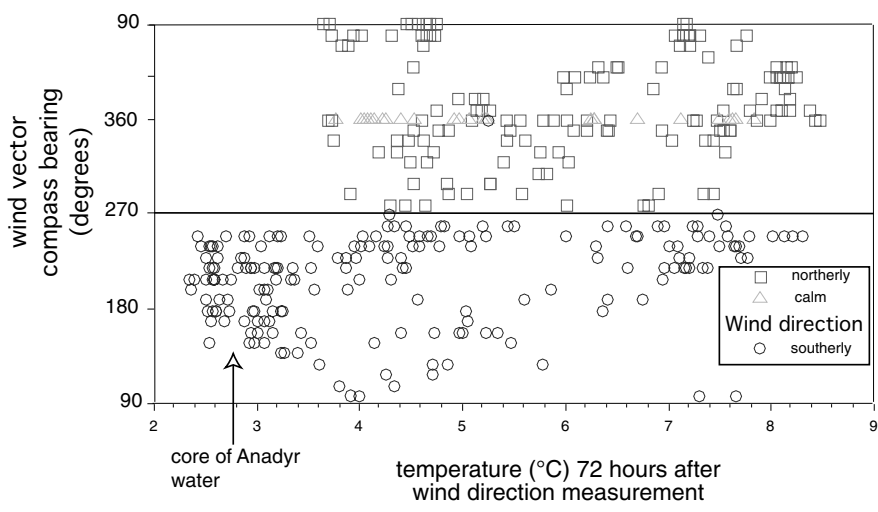

FIG. 4. Seawater temperature at Little Diomede Island in relation to wind vector observed 72 hours earlier at Nome Airport (summer 2001 sampling only). The coldest water temperatures $\left(<3.5^{\circ} \mathrm{C}\right)$, which are associated with nutrient-rich Anadyr water, were observed only after southerly winds. Duration and intensity of wind events are not considered in this analysis.

We therefore concluded that the summer sampling at Diomede, which overlaps much of the data available from shipboard sampling, is much more influenced by runoff (Fig. 6) than the late-winter sampling. Comparison of data from shipboard sampling (Fig. 6) indicates that the oxygen isotope composition of all samples collected at Diomede (mean $\delta^{18} \mathrm{O}=-1.04 \pm 0.40 \mathrm{SD}, \mathrm{n}=71$ ) is significantly different from that of samples collected from shipboard in Bering Strait (mean $\delta^{18} \mathrm{O}=-1.43 \pm 0.95 \mathrm{SD}, \mathrm{n}=250$; unpaired t-test, $p=0.0008$ ). However, we obtain this result because the least saline waters in the Alaskan Coastal Current, which are trapped on the eastern side of Bering Strait (Woodgate and Aagaard, 2005) near the Alaska coastline, were not sampled at any time from the island. When we exclude data above a threshold salinity of 30.5 , there is no significant difference between the $\delta^{18} \mathrm{O}$ values for all water samples collected at Diomede $\left(\right.$ mean $\delta^{18} \mathrm{O}=$ $-0.98 \pm 0.28 \mathrm{SD} ; \mathrm{n}=68$ ) and those for all water samples collected from shipboard platforms anywhere in the Strait (mean $\delta^{18} \mathrm{O}=-1.05 \pm 0.38 \mathrm{SD}, \mathrm{n}=204$; unpaired t-test; $p=0.17$ ). The currently available data indicate that the variability in the oxygen isotope composition of seawater collected from ships in the Bering Strait, except for the least saline samples (salinity $<\sim 30.5$ ), is similar to the variability that can be observed at Diomede.

Two representative nutrient surveys taken within $5 \mathrm{~km}$ of Little Diomede Island are shown in Figure 7. Other data taken from near-bottom waters in April 2003 and surface waters in July 2003 are available from links at the project website (http://arctic.bio.utk.edu/ $\mathrm{AEO} /$ nutrientsurveys.html). Depths of the near-bottom water sampled ranged from $\sim 2 \mathrm{~m}$ close to shore to $30 \mathrm{~m}$ in waters up to $5 \mathrm{~km}$ distant from the island (Figs. 1 and 7). Consequently, the late winter surveys (and summer surveys of bottom waters, for which data are not shown here, but are available on the project website) actually sampled water throughout the water column at various depths from $2 \mathrm{~m}$ to $30 \mathrm{~m}$, and we observed relatively small variations in nutrient concentrations in these

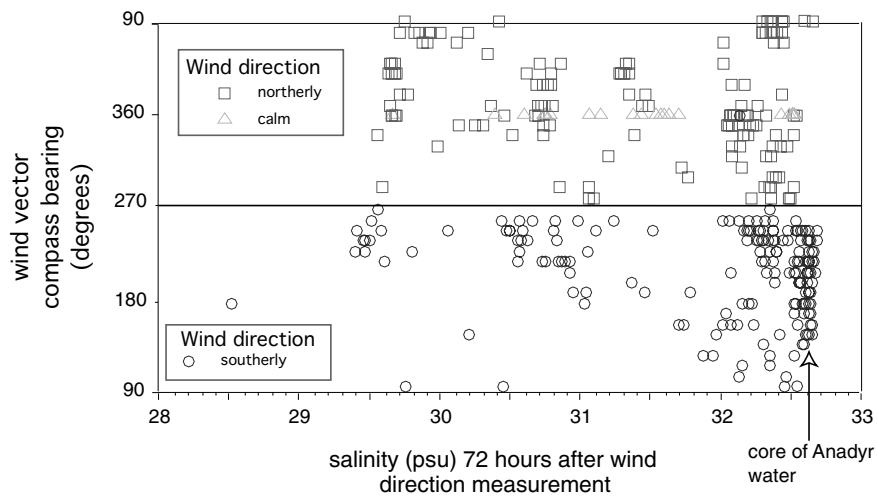

FIG. 5. Seawater salinity at Little Diomede Island in relation to wind vector observed 72 hours earlier at Nome Airport (summer 2001 sampling only). The highest salinities (> 32.5), which are associated with Anadyr water, were observed only after southerly winds. Duration and intensity of wind events are not considered in this analysis.

well-mixed waters regardless of water depth. The exception was the common presence within $\sim 200 \mathrm{~m}$ of the island of anomalous nutrient concentrations greater than the "background" concentrations measured at distances up to $5 \mathrm{~km}$ from the island (Fig. 7). Farther from shore, island effects due to runoff either were absent or fell within the several-hour variability range and error tolerances of our analyses, and thus were much smaller than the changes observed with water-mass and seasonal variability.

We observed biofouling problems from marine microalgae, particularly during summer sampling. In addition to colonizing portions of the water intake, marine macroalgae (Laminaria spp.) were common on rocks in the immediate subtidal zone, as well as at the location of the water intake system that we had established for summer sampling. The summer sampling depth $(4 \mathrm{~m})$ was clearly not sufficient to exclude marine macroalgal debris from the water intake system. Both the internal biofouling by microalgae on the water intake system and the thalli of macroalgae drawn into the pumping system itself are likely to have compromised in-situ chlorophyll measurements made during the summer with the Turner fluorometer (data not shown). After we treated the biofouling by back-flushing the pumping system with household bleach, the fluorometric signal declined to lower levels. By contrast, the late winter fluorometric record remained low (Fig. 3), rising dramatically only at the end of sampling, as the ice broke up. During winter sampling, the water intake system was wrapped in black foam insulation and then became covered by blowing snow and ice, so it is not likely that there was sufficient light to support algal growth on the inside of the Tygothane tubing.

Relatively low photosynthetically active radiation levels $\left(\sim 20 \mu \mathrm{E} \mathrm{m}^{-2} \mathrm{~s}^{-1}\right)$ observed at $11 \mathrm{~m}$ under midday summer conditions suggest that if the entrance to the water intake were placed at a similar depth or deeper, biofouling by marine algae in the proposed year-round pumping system would not be a constant concern. 


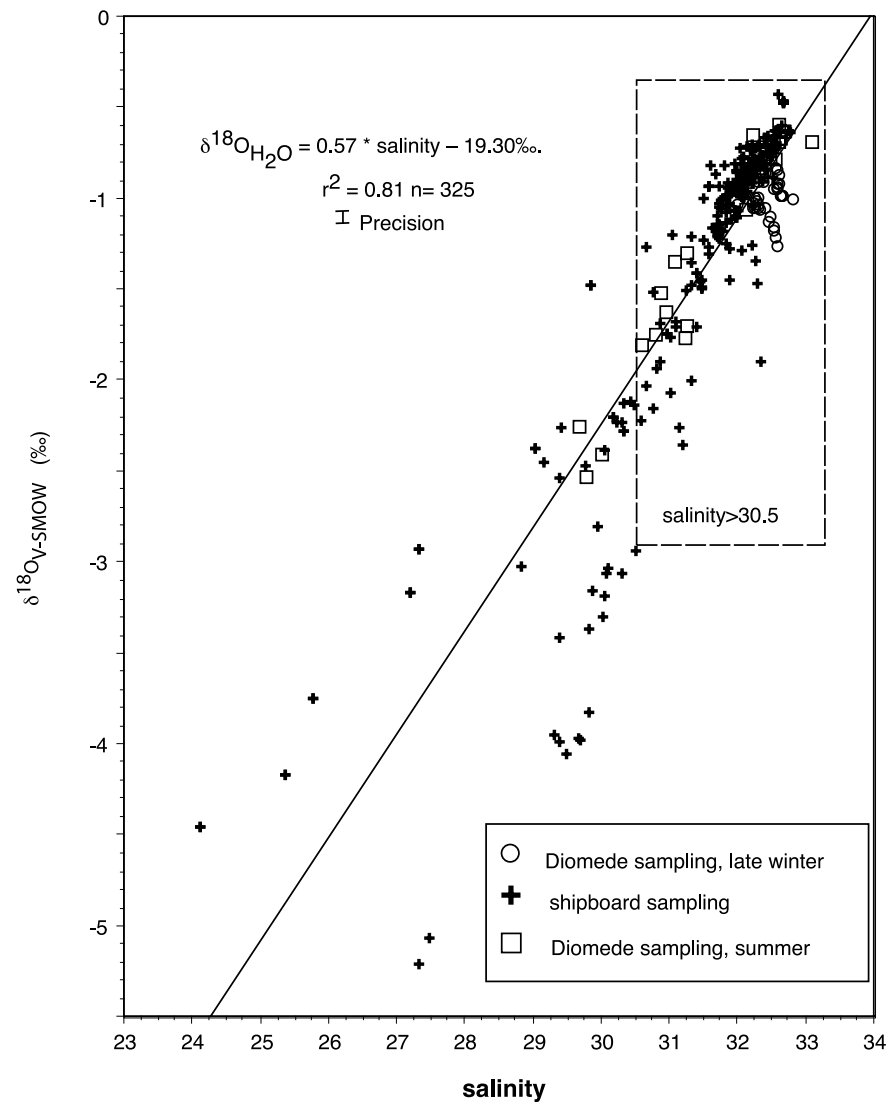

FIG. 6. Relationship between salinity and $\delta^{18} \mathrm{O}$ values of seawater samples collected in summer (squares) and late winter (circles) at Little Diomede Island. Crosses correspond to samples obtained from shipboard during 1988-2003 (see Table 1). Comparison of samples with salinity greater than 30.5 (in dashed box) indicates that stable oxygen isotope composition of samples collected at Little Diomede Island is not significantly different from that of samples collected from shipboard platforms (see text).

\section{DISCUSSION}

The fieldwork at Little Diomede Island over the past several years suggests that an environmental observation system there that includes a seawater inlet system would contribute significantly to understanding of the Bering Strait inflow into the Arctic Ocean. For example, the data collected to date using our interim pumping systems have documented the timing of the spring phytoplankton bloom and the annual shift from melted sea ice to runoff in surface waters. Installation of a year-round system that is useful for a wide range of studies, however, would require professional engineering expertise. A separate geotechnical study suggests that directional drilling under the seafloor at Diomede is feasible and can provide a year-round pumping capability (Peratovich, Nottingham and Drage Inc., 2002). Directional drilling would create very limited environmental disturbance and would minimize the portion of the intake system vulnerable to storm and ice damage. Our experience with physical damage to our initial pumping systems in both winter and summer suggests that expectations of permanent, continuous water flow with these comparatively inexpensive over-seafloor or over-ice intake systems are unrealistic.
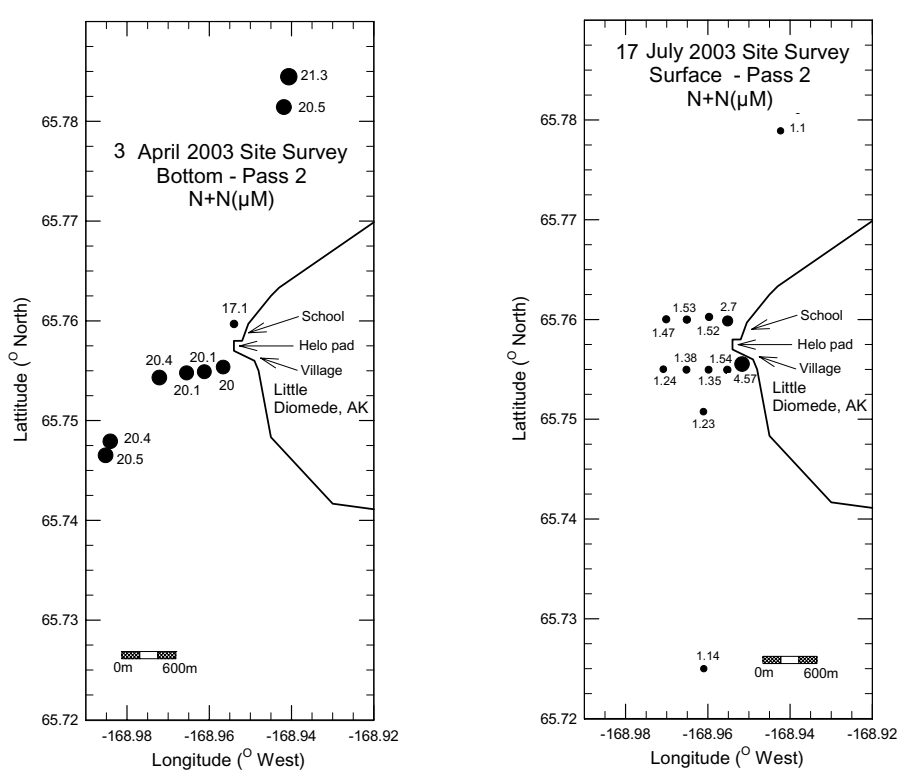

FIG. 7. Results from two nutrient surveys conducted in the vicinity of Diomede, one in spring (3 April 2003) and one in summer (17 July 2003). These nitrate + nitrite $(\mathrm{N}+\mathrm{N})$ data suggest the presence of significant local effects at three stations close to the island. However, at stations near the proposed offshore intake location, to the west of the helicopter pad, $\mathrm{N}+\mathrm{N}$ concentrations are similar to those measured well away from the island. Note that bottom-water samples were collected from waters of various depths ( $2 \mathrm{~m}$ to $30 \mathrm{~m}$; see text). The differences of $\sim 19 \mu \mathrm{M}$ between the late winter survey and the summer survey are consistent with seasonal variability and ranges observed during other studies (e.g., Codispoti et al., 2005) and are, as expected, much larger than the differences found within each season. To assess short-term variability, most surveys included two sampling circuits over ca. six hours. Differences between "pass 1" and "pass 2" values at stations near the approximate location of our proposed intake and those stations farther offshore were similar to the betweencircuit variability observed at individual stations. A more comprehensive suite of survey results is available at http://arctic.bio.utk.edu/AEO/ nutrientsurveys.html.

Water-column variation was high during our summer sampling periods, and changes occurred rapidly in apparent response to wind shifts. The water chemistry shifts that were observed (Fig. 2a-e) are consistent with expectations of Ekman effects from surface winds (Aagaard et al., 1985). Under northerly winds, relatively cold, saline, nutrient-rich Anadyr water is deflected westward towards the Russian Federation coast, and it is replaced by warm, less saline, nutrient-poor Alaska coastal water from the eastern side of Bering Strait. Under these conditions, the reduced influence of high-nutrient water should also reduce biological productivity. Conversely, southerly winds should promote higher productivity and a greater influence of the cold, relatively saline and nutrient-rich Anadyr water. Southerly winds would also increase total transport northward through the Strait (Roach et al., 1995), but our observations relate most closely to the horizontal (westto-east) position of water masses flowing northward through the Strait, rather than to any attempt to describe mass transport fluxes. Although it is beyond the scope of our sampling at Diomede to quantify the relative contributions of nutrient-rich Anadyr water and nutrient-poor Alaska coastal water to Bering Strait inflow, Coachman et al. (1975) observed that local wind stress could affect 
transport rates of the lower-salinity water through the Bering Strait. It seems possible that over longer time scales, the volume of freshwater incorporated into the Bering Strait flow after a persistent change in atmospheric forcing could also affect globally important climatic processes, such as the North Atlantic overturning circulation (Shaffer and Bendtsen, 1994; Woodgate and Aagaard, 2005). Any longer-term shift in the characteristics of the Bering Strait inflow would also affect the degree of stratification of Arctic surface waters, as well as the spatial extent of surface waters influenced by the Pacific inflow. For example, greater export of Alaska coastal water than Anadyr water through the Bering Strait, a condition associated with anticyclonic northerly winds, would bring a larger freshwater flux into the Chukchi Sea. Since the summer temperature of Alaska coastal water is relatively high (Fig. 2c), ice melt could also increase. Biological populations such as walruses and ice-associated seals could be affected by such decreases in seasonal sea ice (Kelly, 2001), as could various biological processes.

In a more general sense, these short-term, wind-driven impacts on chemical variability in the Bering Strait inflow that we observed have implications for the appropriate way to monitor the large fluxes of nutrients that pass into the Arctic Ocean through the Bering Strait. If surface winds influence the boundaries between nutrient-rich Anadyr water and nutrient-poor Alaska coastal water, it is possible that the overall flux of nutrients into the Arctic could also be influenced by the intensity and duration of atmospheric forcing. Clearly, surveys of the nutrient distribution across Bering Strait that are obtained from shortduration shipboard sampling can provide only an incomplete representation of this nutrient flux, and higherresolution, time-series observations are needed.

An outcome of the late winter sampling was that we succeeded in fluorometrically recording the spring phytoplankton bloom as the ice cover supporting our pumping system was melting away (Fig. 3). It is problematic whether this measurement would have been possible with a fluorometer moored to the sea floor in deeper water. Increases in chlorophyll directly followed decreases in salinity attributable to melted sea ice, and all nutrients declined to very low levels.

The small change in $\delta^{18} \mathrm{O}$ values over the course of the winter sampling (range of $\sim 0.5 \%$ o) indicates that the watermass structure was much more uniform than in the summer (Fig. 3). Since melted sea ice decreases salinity without having a large impact on the oxygen isotope composition of seawater, we can conclude that the slowly decreasing salinities measured during this late winter period were primarily the result of increasing ice melt in Bering Strait surface waters (Cooper et al., 1997).

We observed agreement between the mean oxygen isotope composition of seawater transported past Little Diomede Island in the summer $\left(\delta^{18} \mathrm{O}=-1.11 \%_{\circ} \pm 0.56 \mathrm{SD}\right.$, $\mathrm{n}=33$ ) and that of upper halocline waters with a Bering Strait origin in the Arctic Ocean $\left(\delta^{18} \mathrm{O}=-1.1 \% o\right)$. Thus, for this summer sampling period, the oxygen isotope composition of the Diomede intake waters appears to be representative of the oxygen isotope composition of the integrated Bering Strait water that is ultimately incorporated into the upper halocline of the Arctic Ocean. Obviously winter cooling and brine injection would affect the temperature and salinity of these waters before they are incorporated into the upper halocline, but these processes would not materially affect $\delta^{18} \mathrm{O}$ values. In late winter, by comparison, the mean $\delta^{18} \mathrm{O}$ value for water flowing past Little Diomede was $-0.98 \%$ $\pm 0.12(n=39)$.

This implies that the mean $\delta^{18} \mathrm{O}$ values (and correlated nutrient concentrations) we observed in August 2001 must be somewhat less negative (by $\sim 0.1 \%$ ) than the long-term summer mean needed to achieve an integrated $\delta^{18} \mathrm{O}$ value in the upper halocline of $-1.1 \%$ o that includes both summer and winter water. A major benefit of evaluating $\delta^{18} \mathrm{O}$ values is that isotope composition of seawater is only modestly affected by sea-ice formation processes (Cooper, 1998), whereas salinity is raised by brine injection during sea-ice formation. (The Arctic Ocean upper halocline has a salinity of 33.1 in water with high nutrient concentrations associated with the Pacific water inflow, but we observed only a range of 31 to 32.5 during summer sampling at Diomede.)

Despite these complexities in the small seasonal differences in the oxygen isotope composition of Bering Strait waters, the overall variability in the oxygen isotope composition of seawater collected from ships in Bering Strait is similar to that observed at Diomede over the monthlong, near-surface, continuous sampling periods discussed here. The key exception is that the Diomede pumping system did not sample the least saline shipboard samples present on the easternmost portion of the Strait (salinity $<30.5$; Fig. 6).

A single water intake infrastructure at Diomede clearly has limitations reflecting the single-point intake source, although the high variability in summer water-mass characteristics indicates that wind forcing will bring varied water masses to any sampling intake. Ultimately shortterm extensive surveys, time-series experiments, remote sensing, and models should be combined to produce the best possible estimates of the fluxes through the Bering Strait. At present, the United States has no capability for continuous onshore scientific seawater analyses in any of its ice-covered territorial seas (Bering, Chukchi, and Beaufort), which are also the North American continent's largest shelves. Specific advantages of a shore-based system that are therefore unavailable in the U.S. Arctic are the wide variety of analyses that can be applied to samples collected from such a system and the documentation of surface layer processes, such as the timing of the spring phytoplankton bloom, that are problematic to record from fluorometers moored in deeper water. Other advantages of a shore-based system would be the potential to document seasonal changes in phytoplankton and zooplankton communities and perform tracer analyses that require large 
volumes of water. Furthermore, a time-series station on Little Diomede would provide some mid-strait scientific infrastructure for other types of studies (e.g., enumerating marine mammals during migrations) and could serve as a node for autonomous underwater vehicles.

As noted earlier, surveys indicate that runoff impacts on nutrient concentrations in waters close to the island are most significant from shore to $100-200 \mathrm{~m}$ out (Fig. 7). Since constructing an undersea water intake $200 \mathrm{~m}$ or more away from the island is considered practical (Peratovich, Nottingham and Drage, Inc., 2002), it seems reasonable to suggest that "island" effects associated with runoff and human activities can be rendered insignificant.

Our measurements of photosynthetically active radiation (PAR) levels were made at mid-day in July 2003, near the annual maximum for solar radiation. Observed PAR was $\sim 20 \mu \mathrm{E} \mathrm{m}^{-2} \mathrm{~s}^{-1}$ at $11 \mathrm{~m}$, which is slightly above typical shade-adapted compensation levels $\left(\sim 10 \mu \mathrm{E} \mathrm{m}^{-2} \mathrm{~s}^{-1}\right)$ for Arctic algae (Cota and Smith, 1991). Consequently, some biofouling of an intake by both marine plants and animals can be expected, particularly during the summer, and will require management. Periodic backflushing of the intake with warm freshwater and preventing light from penetrating the intake pipe may be all that is required to control epiphytic algal growth. Other fouling (e.g., barnacles and bryozoans) could be managed by constructing a system with two parallel intake pipes, only one of which would be in use at any time. Alternation of seawater intake pipes is a proven design used elsewhere to control zoological biofouling (e.g., Monterey Bay Aquarium).

The Peratovich, Nottingham and Drage, Inc. (2002) report indicates that directional drilling is the preferred construction method for an underground, underwater intake system at Little Diomede Island with an estimated pipeline life of 25 to 50 years. Capital construction costs could approach US\$3 million under adverse weather conditions and are similar in scale to the cost of other Arctic research logistics, such as US\$2 million to move U.S polar class icebreakers from their home port in Seattle to the Atlantic sector of the Arctic through the Panama Canal (Simon Stephenson, U.S. National Science Foundation, pers. comm. 2005). Over time, these construction costs are also competitive with recurring annual ship-time costs for turning around and servicing moorings. An ancillary benefit of placing an environmental observatory on Little Diomede is modest economic and educational enrichment of the local community. We have already contributed to improved Internet access for the island, and we have provided temporary employment for some residents. Perhaps more important is that the residents of Diomede, because of their reliance on subsistence hunting and local natural resources, share with the scientific community a deep interest in assessing changes in the Bering Strait ecosystem. The exchange of ideas on climate and ecosystem change between local residents and the scientists participating in the observatory is likely to enrich both groups. The intersection of Iñupiat cultural and scientific research interests could be transformational at this location, which is recognized by both groups as crucial both for understanding Arctic environmental processes and for the abundant marine life that helps support the local community.

\section{ACKNOWLEDGEMENTS}

We thank the people of Diomede, and specifically the IRA Council, the Inalik Village Corporation, and the city government for permission to work on the island and for providing sustained, invaluable assistance over several years. The Bering Strait School District and its staff at the Diomede School provided space and utilities for us to undertake these measurements. Arianne Balsom, Jim Bartlett, Dave Brown, Emily Cooper, Steve Gaurin, Eric Haberkern, Jacob Hoehn, Holly Kelly, and Rebecca Pirtle-Levy are among the individuals we thank for providing assistance on the island or help in analyzing samples and data. We also received logistical assistance throughout this work from the Canadian and U.S. Coast Guards (CCGS Sir Wilfrid Laurier, USCGC Polar Star, and USCGC Healy). Dr. Zheng-Hua Li (University of Tennessee) performed some of the oxygen isotope measurements presented here. We also thank Rebecca Woodgate, Seth Danielson, and Knut Aagaard for providing unpublished salinity data and collecting samples for oxygen isotope measurements during shipboard work in Bering Strait, supported through grants from the U.S. Office of Naval Research (\#N00014-99-1-0345) and National Science Foundation (OPP-0125082). Other work in this study was supported by the U.S. National Science Foundation, Office of Polar Programs. We thank four anonymous reviewers who provided constructive comments on earlier versions of the manuscript and Luisa Alexander Izzo for her thorough copy-editing.

\section{REFERENCES}

AAGAARD, K., and CARMACK, E.C. 1989. The role of sea ice and other fresh water in the Arctic circulation. Journal of Geophysical Research 94(C10):14485-14498.

AAGAARD, K., ROACH, A.T., and SCHUMACHER, J.D. 1985. On the wind-driven variability of the flow through Bering Strait. Journal of Geophysical Research 90(C4):7213-7221.

BAUCH, D., SCHLOSSER, P., and FAIRBANKS, R.G. 1995. Freshwater balance and the sources of deep and bottom waters in the Arctic Ocean inferred from the distribution of $\mathrm{H}_{2}{ }^{18} \mathrm{O}$. Progress in Oceanography 35:53-80.

CLEMENT, J.L., COOPER, L.W., and GREBMEIER, J.M. 2004. Late winter water column and sea ice conditions in the northern Bering Sea. Journal of Geophysical Research 109: C03022, doi:10.1029/2003JC002047.

COACHMAN, L.K., AAGAARD, K., and TRIPP, R.B. 1975. Bering Strait: The regional physical oceanography. Seattle: University of Washington Press. $172 \mathrm{p}$.

CODISPOTI, L.A., FLAGG, C., KELLY, V., and SWIFT, J.H. 2005. Hydrographic conditions during the 2002 SBI process experiments. Deep-Sea Research II: Topical Studies in Oceanography 52(24-26):3199-3226. 
COOPER, L.W. 1998. Isotopic fractionation in snow cover. In: McDonnell, J.J., and Kendall, C. Isotopic tracers in catchment hydrology. Amsterdam: Elsevier. 119-136.

COOPER, L.W., WHITLEDGE, T.E., GREBMEIER, J.M., and WEINGARTNER, T. 1997. The nutrient, salinity, and stable oxygen isotope composition of Bering and Chukchi seas waters in and near the Bering Strait. Journal of Geophysical ResearchOceans 102(C6):12563-12573.

COOPER, L.W., COTA, G.F., POMEROY, L.R., GREBMEIER, J. M., and WHITLEDGE, T.E. 1999. Modification of NO, PO, and NO/PO during flow across the Bering and Chukchi shelves: Implications for use as Arctic water mass tracers. Journal of Geophysical Research-Oceans 104(C4):7827-7836.

COOPER, L.W., HONG, G.H., BEASLEY, T.M., and GREBMEIER, J.M. 2001. Iodine-129 concentrations in marginal seas of the north Pacific and Pacific-influenced waters of the Arctic Ocean. Marine Pollution Bulletin 42:1347-1356.

COOPER, L.W., LARSEN, I.L., GREBMEIER, J.M., and MORAN, S.B. 2005. Detection of rapid deposition of sea ice-rafted material to the Arctic Ocean benthos demonstrated using the cosmogenic tracer 7Be. Deep-Sea Research II: Topical Studies in Oceanography 52(24-26):3452-3461.

COTA, G.F., and SMITH, R.E.H. 1991. Ecology of bottom ice algae: II. Dynamics, distributions and productivity. Journal of Marine Systems 2:279-295.

DEHN, L.A., SHEFFIELD, G.G., FOLLMAN, E.H., DUFFY, L.K., THOMAS, D.L., BRATTON, G.R., TAYLOR, R.J., and O'HARA, T.M. 2005. Trace elements in tissues of phocid seals harvested in the Alaskan and Canadian Arctic: Influence of age and feeding ecology. Canadian Journal of Zoology 83: 726-746.

EKWURZEL, B., SCHLOSSER, P., MORTLOCK, R.A., FAIRBANKS, R.G., and SWIFT, J.H. 2001. River runoff, sea ice meltwater, and Pacific water distribution and mean residence times in the Arctic Ocean. Journal of Geophysical ResearchOceans 106(C5):9075-9092.

GREBMEIER, J.M., COOPER, L.W., and DENIRO, M.J. 1990. Oxygen isotopic composition of bottom seawater and tunicate cellulose used as indicators of water masses in the northern Bering and Chukchi seas. Limnology and Oceanography 35(5):1182-1195.

GREBMEIER, J.M., SMITH, W.O., and CONOVER, R.J. 1995. Biological processes on Arctic continental shelves: Ice-oceanbiotic interactions. In: Smith, W.O., and Grebmeier, J.M., eds. Arctic oceanography: Marginal ice zones and continental shelves. Washington, D.C.: American Geophysical Union. 231-261.

GREBMEIER, J.M., OVERLAND, J.E., MOORE, S.E., FARLEY, E.V., CARMACK, E.C., COOPER, L.W., FREY, K.E., HELLE, J.H., McLAUGHLIN, F.A., and McNUTT, S.L. 2006. A major ecosystem shift in the northern Bering Sea. Science 311: 1461-1464, doi:10.1126/science. 1121365 .

GUALTIERI, L., and BRIGHAM-GRETTE, J. 2001. The age and origin of the Little Diomede Island upland surface. Arctic 54(1):12-21.

HARRISON, D.E., and LARKIN, N.K. 1997. Darwin sea level pressure, 1876-1996: Evidence for climate change? Geophysical Research Letters 24(14):1779-1782.
KELLY, B.P. 2001. Climate change and ice breeding pinnipeds. In: Walther, G.-R., Burga, C.A., and Edwards, P.J., eds. "Fingerprints" of climate change: Adapted behaviour and shifting species' ranges. London and New York: Kluwer Academic/ Plenum Publishers. 43-55.

KÉROUEL, R., and AMINOT, A. 1997. Fluorometric determination of ammonia in sea and estuarine waters by direct segmented flow analysis. Marine Chemistry 57:265-275.

KHIM, B.-K., KRANTZ, D.E., COOPER, L.W., and GREBMEIER, J.M. 2003. Seasonal discharge of estuarine freshwater to the western Chukchi Sea shelf identified in stable isotope profiles of mollusk shells. Journal of Geophysical Research 108: (C9) 3300, doi:10.1029/2003JC001816.

LEITH, C.E. 1973. The standard error of time-averaged estimates of climatic means. Journal of Applied Meteorology 12: 1066-1069.

LOVVORN, J.R., RICHMAN, S.E., GREBMEIER, J.M., and COOPER, L.W. 2003. Diet and body conditions of spectacled eiders wintering in pack ice of the Bering Sea. Polar Biology 26:259-267.

LOVVORN, J.R., COOPER, L.W., BROOKS, M.L., DE RUYCK, C.C., BUMP, J.K., and GREBMEIER, J.M. 2005. Organic matter pathways to zooplankton and benthos under pack ice in late winter and open water in late summer in the north-central Bering Sea. Marine Ecology Progress Series 291:135-150.

MACDONALD, R.W., CARMACK, E.C., McLAUGHLIN, F.A., ISEKI, K., MACDONALD, D.M., and O'BRIEN, M.C. 1989. Composition and modification of water masses in the Mackenzie Shelf Estuary. Journal of Geophysical Research 94(C12): $18057-18070$.

MACDONALD, R.W., SAKSHAUG, E., and STEIN, R. 2004. The Arctic Ocean: Modern status and recent climate change. In: Stein, R., and Macdonald, R.W., eds. The organic carbon cycle in the Arctic Ocean. Berlin: Springer-Verlag. 6-21.

PERATOVICH, NOTTINGHAM ANDDRAGE, INC. 2002. Little Diomede Island Seawater Intake Feasibility Report. Prepared for VECO Polar Resources, Anchorage, 1506 West 36th Avenue, Anchorage, Alaska 99503. 21 p.

ROACH, A.T., AAGAARD, K., PEASE, C.H., SALO, S.A., WEINGARTNER, T., PAVLOV, V., and KULAKOV, M. 1995. Direct measurements of transport and water properties through the Bering Strait. Journal of Geophysical Research 100: $18443-18457$.

SAMBROTTO, R.N., GOERING, J.J., and McROY, C.P. 1984. Large yearly production of phytoplankton in the western Bering Strait. Science 225(4667):1147-1150.

SCOR (SCIENTIFIC COMMITTEE ON OCEANOGRAPHIC RESEARCH). 1996. Protocols for the Joint Global Ocean Flux Study (JGOFS) Core measurements, JGOFS Report 19. Bergen, Norway: SCOR, International Council of Scientific Unions. $170 \mathrm{p}$.

SHAFFER, G., and BENDTSEN, J. 1994. Role of the Bering Strait in controlling North Atlantic Ocean circulation and climate. Nature 367:354-357.

SIMPKINS, M.A., HIRUKI-RARING, L.M., SHEFFIELD, G., GREBMEIER, J.M., and BENGSTON, J.L. 2003. Habitat selection by ice-associated pinnipeds near St. Lawrence Island, Alaska in March 2001. Polar Biology 26:577-586. 
SPRINGER, A.M., McROY, C.P., and FLINT, M.V. 1996. The Bering Sea green belt: Shelf-edge processes and ecosystem production. Fisheries Oceanography 5(3-4):205-223.

STEELE, M., MORISON, J., ERMOLD, W., RIGOR, I., ORTMEYER, M., and SHIMADA, K. 2004. Circulation of summer Pacific halocline water in the Arctic Ocean. Journal of Geophysical Research-Oceans 109: C02027, doi:10.1029/ 2003JC002009.

WALSH, J.J., McROY, C.P., COACHMAN, L.K., GOERING, J.J., NIHOUL, J.J., WHITLEDGE, T.E., BLACKBURN, T.H., PARKER, P.L., WIRICK, C.D., SHUERT, P.G., GREBMEIER, J.M., SPRINGER, A.M., TRIPP, R.D., HANSELL, D.A.,
DJENIDI, S., DELEERSNIJDER, E., HENRICKSEN, K., LUND, B.A., ANDERSEN, P., MÜLLER-KARGER, F.E., and DEAN, K. 1989. Carbon and nitrogen cycling within the Bering/ Chukchi seas: Source regions for organic matter effecting AOU demands of the Arctic Ocean. Progress in Oceanography 22: 277-359.

WIJFFELS, S.E., SCHMITT, R.W., BRYDEN, H.L., and STIGEBRANDT, A. 1992. Transport of freshwater by the oceans. Journal of Physical Oceanography 22:155-162.

WOODGATE, R.A., and AAGAARD, K. 2005. Revising the Bering Strait freshwater flux into the Arctic Ocean. Geophysical Research Letters 32: L02602, doi:10.1029/2004GL021747. 